\begin{abstract}
Alienation and estrangement in Dinaw Mengestu's All Our Names
In this article I explore issues of negotiating cultural identity in new geopolitical spaces as presented in Dinaw Mengestu's All Our Names. I examine the portrayal of a liminal character living in Uganda and America and how the author narrates his daily experiences of negotiating identity in order to underscore the power of hierarchies of ethnicity, class, race, and nationalistic discourses at play in determining who belongs and who does not. I analyse the ways in which names are used as narrative strategy to show that identity is never singular or fixed but plural and continuous. I explore how, through Isaac's unnaming, naming, and renaming, Mengestu contests the fixity of names and identity by indicating naming as a processual act and how a person's identity is layered and thus cannot be fully contained within a single marker. Drawing upon the concepts of hybridity, third space, and cosmopolitanism, I demonstrate how subject position and cultural identity are not fixed into definite categorical distinctions but are fluid concepts. Mengestu does not only raise possibilities of belonging beyond the confines of a nation or community, but also presents a cosmopolitan world where negotiation and belonging is difficult because of power differences, racism, marginalisation, and discrimination. Keywords: cultural identity, cosmopolitanism, hybridity, alienation, racism.
\end{abstract}

\title{
Introduction
}

In this article, I am motivated by debates surrounding identity and diaspora in different academic disciplines. Theorists like Homi K. Bhabha, Stuart Hall, Paul Gilroy, and Kwame Appiah, to name but a few, have explored new ways of interrogating diasporic identities because discourses of nationalism or race as modes of belonging placed individuals in fixity of roots and origins. In Beginning Postcolonialism, McLeod rightly observes that:

nationalist discourses attempt to construct "deep, horizontal comradeship" by setting "norms and limits" for the nation's people [such that] although migrants [...] pass through the political borders of nations [...] gaining entrance to the new place, such "norms and limits" can be used to exclude the migrants from being accommodated inside the imaginative borders of the nation [...] migrants can be deemed not to belong there and [...] from thinking of the new land as their home. (212)

These discourses of nationalism, race, or ethnicity are no longer suitable as models of identity and belonging in the present time because of the increase in migration of people across nations which has remarkably altered the way individuals think of their identity in the new places.

Hall states that an essentialist concept of identity is "constructed on the back of recognition of some common origin or shared characteristics with another person or group, or with an ideal, and with the natural closure of solidarity and allegiance established on this foundation" (16). As Culler indicates, this notion of identity is fixed and constant throughout an individual's life and that it is something given by birth (115). Hall argues against this essentialist view of identity as fixed, proposing that identity involves constant change and is never static. Identity is influenced by structures of power, race, and ethnicity and is "more the product of the marking of difference and exclusion" (17). Difference plays a role in fluidity of identity.

Ruth Kwamboka Openda recently graduated with a Master of Arts in Literature from the University of Nairobi and teaches Literature and English at Embu County Secondary School in Eastern Kenya.

Email: ruthopenda@gmail.com

(D) https://orcid.org/0000-0001-5526-6947

D0l: https://doi.org/10.17159/tl.1581i.8210

DATES:

Submitted: 23 April 2020; Accepted: 29 November 2020; Published: 29 April 2021 
Bhabha discusses the concept of hybridity in The Location of Culture (1994). Hybrid identity is a process that emerges in the liminal space where two cultures integrate. He goes on to state that it is necessary:

$[\ldots][t] o$ think beyond narratives of originary and initial subjectivities and to focus on those moments or processes that are produced in the articulation of cultural differences. These 'in-between' spaces provide the terrain for elaborating strategies of selfhood-singular or communal-that initiate new signs of identity and innovative sites of collaboration, and contestation, in the act of defining the idea of society itself. (1-2)

Bhabha explains the process of cultural negotiation where two opposing cultures clash and articulate their differences. The in-between space is where the new cultural identity that is hybrid is created. This hybridity of cultural identities is not a product of assimilation of two cultures but of something new. This notion presents cultural identity as in a process, not something fixed. It keeps changing and is not limited to a geopolitical community.

Bhabha further states "for me the importance of hybridity is not to be able to trace two original moments from which the third emerges, rather hybridity to me is the 'Third Space,' which enables other positions to emerge" ("The Third Space" 211). The third space allows for new possibilities to emerge and questions the established fixed categories of culture and identity. Bhabha argues that the liminal space "opens up possibilities of a cultural hybridity that entertains difference without an assumed or imposed hierarchy" (4) and, in so doing, "instead of exclusion and rejection, the new space, thus, has the capacity and tendency to include and accept" (Chakraborty 149).

In this article I draw attention to the fluid nature of cultural identity. I am interested in exploring the ways in which the characters in the novel define and (re)construct their cultural identities as they try to fit into the socio-culture of the host community but remain on the periphery. Such characters face discrimination and marginalisation as they are not accommodated within the imaginative borders of the nation. Their in-between state of being affords them a chance to reinvent their identity, therefore achieving a plural and hybrid identity.

In examining the notions of identity and belonging in the contemporary world "cosmopolitanism has reemerged as a way of understanding the implications of social, cultural and political transformations and contacts that transcend territorial boundaries" (Voronkova l). Vertovec and Cohen state that cosmopolitanism can refer to:

a vision of global democracy and world citizenship; [...] it points to possibilities for shaping new transnational frameworks for making links between social movements. [...] [It is] a non-communitarian, post-identity politics of overlapping interests and heterogeneous or hybrid publics [which] challenge conventional notions of belonging, identity and citizenship; [...] and descriptively [cosmopolitanism] address[es] certain socio-cultural processes or individual behaviours, values or dispositions manifesting a capacity to engage cultural multiplicity. (l)

Cosmopolitanism is thus premised on a sense of belonging that transcends national borders, anti-essentialist notions of identity, and calls for willingness to engage with the other by stepping outside the definitive modes of belonging and identification. It recognises possibility of multiple identities and "emphasizes cultural hybridity to challenge the relevance of national cultures and arbitrariness of distinction between us (co-nationals) and them (foreigners)" (Boucher, Aubert and Guérard de Latour 23). Cosmopolitan identity is constantly in a state of becoming rather than being.

This idea of cosmopolitanism has been criticized because, as Bhabha argues, it "configures the planet as a concentric world of national societies extending to global villages. It is a cosmopolitanism of relative prosperity and privilege founded on ideas of progress that are complicit with neo-liberal forms of governance" (Location of Culture xiv). Pollock et al. argue that:

cosmopolitanism of the contemporary times does not spring from the capitalized "virtues" of Rationality, Universality, and Progress, nor is it embodied in the myth of the nation writ large in the figure of the citizen of the world; as cosmopolitans today are victims of modernity, failed by capitalism's upward mobility, and bereft of those comforts and customs of national belonging. (582)

Such arguments have emphasised the need to reconsider the celebratory notion of cosmopolitanism in relation to minority groups because of its "overtones of urbanity and sophistication" (Ashcroft 13) and free movement because it does not consider power hierarchies in the global world. As Ashcroft further argues, "people who must move across borders, flee the nation either as economic or political refugees, or as subjects oppressed in some way by the state power. Such people are undecidedly unfree" (13). Bhabha coined the term "vernacular cosmopolitan- 
ism" to address the problem of too eager claims of world citizenship associated with cosmopolitanism. He states "the notion of borderless cosmopolitan community seems inadequate in relation to the millions of refugees and migrants fleeing violence and poverty propo[sing] a cosmopolitan community envisaged in marginality" (Werbner 497, emphasis in original). Vernacular cosmopolitanism recognises the minorities' daily experiences in the new spaces they move to and the inequalities that come with their mobilities.

Drawing upon the concepts of hybridity, third space, and cosmopolitanism, I demonstrate that subject position and cultural identity are not definite categorical distinctions but are fluid concepts. I urge for what Gerard Delanty calls critical cosmopolitanism regarding "multiple ways of existing in the social world based on the principle of openness created out of the encounter of the local and the global which considers the minority with their struggles in the global world" ("The Cosmopolitan Imagination" 27). Vernacular and critical cosmopolitanisms contest the experiences of discrimination and marginalisation that minorities go through as they are not accommodated within the imaginative borders of the nation.

\section{No place to belong}

All Our Names captures the experiences of Isaac (D-) and his friend Isaac in Uganda, and later his relationship with Helen in America. Isaac's search for identity and a place to belong starts as a young boy in his home in Ethiopia where he always felt like an outsider; always dreaming of leaving home, a dream he later fulfils when he leaves for Uganda. The narrator was estranged from his own family because he felt burdened by the traditions and the customs his community believed in. He imagines that in Uganda he would belong and make it a place to call home. However, he finds himself always on the margins, isolated as a foreigner and poor boy from a small village in Ethiopia. Isolation and alienation mark his life in Uganda.

Mengestu employs a split narrative technique in the novel by using two narrators-Isaac whose real name we come to find out is "D-" and Helen. Through a manipulation of focalisation by using these two characters, he brings about plurality of perspectives in the novel. The chapters titled Isaac contain Isaac's narrative of his experiences in Uganda while the alternating ones titled Helen narrate Helen's perspective whereby we get to learn of Isaac's life in America and the romantic relationship between the two-Helen and Isaac. The use of two narrators, as Robyn McCallum argues, is one way of "representing a plurality of voices, consciousness and discourses in the narrative, of structuring a narrative as a dialogue between different cultural and ideological positions" (63). Mengestu's use of two narrators - of different genders, in different cultural spaces - in alternating chapters presents different perspectives on questions of identity and belonging in these two cultural spaces-Uganda and America.

In this article, I use the terms "alienation" and "estrangement" to refer to the immigrants' experiences of isolation as outsiders and racialised others in the host societies. Immigrant here refers to the characters who are displaced from their homelands for political, economic, and social reasons. Derek Hook states that "the concept of alienation emphasises a sense of eruption-estrangement - in the relationship between the individual and the things, objects and people around him or her" (95). Jan Hadja offers a similar definition of alienation as "an individual feeling of uneasiness or discomfort which reflects his exclusion or self-exclusion from social and cultural participation; an expression of non-belonging or non-sharing, an uneasy awareness or perception of unwelcome contrast with others" (756-7). These definitions capture Isaac's experiences of always being on the margins, excluded and unwelcome as a foreigner in Uganda and as racialised other in America.

In the novel, Isaac is portrayed as a permanent outsider as evidenced in his experiences back home, in Ugan$\mathrm{da}$, and in America. He feels alienated as much in his home as in Uganda. His sense of not belonging is underscored by the name "Bird" his father gave him as a child, because he thought his son "lived high in the sky, far above everyone else" (All Our Names 179). The nickname alludes to the narrator's "wandering-[his] statelessness as a state of being" (Sacks). It symbolises the freedom associated with not belonging to a particular place. The narrator is just like a bird that migrates from place to place, temporarily stopping in its journey but never settling. He has never felt a sense of belonging to any place. Even back home he felt like an outsider always dreaming of leaving. This is later evidenced in the novel by Helen who discloses that Isaac told her once he had accepted the idea that "there was no place in the world where he felt fully at ease but [he] didn't know it was permanent" (Names 99).

The narrator seeks to reconfigure his own identity away from his family and culture because at home he always felt estranged from his family, culture, and what the community believed in. "When I lived with my parents I used to take long walks by myself even when I was very young and was forbidden from doing so. I couldn't help 
it. I was restless. I always felt out of place" (99). The narrator's estrangement in his home reconfigures the idea of home as a place where one belongs as Georgiou posits. According to her, a home is the "symbolic and real place that becomes a synonym to familiarity, intimacy, security and identity against the unknown, the distant and the large" (85). Contrary to the notion of home, the narrator feels like a "prisoner" (Names 177) while at home, due to a sense of separation from all the traditions and customs that the community upholds. He stresses the sense of estrangement growing up in his village-dreaming about leaving and making plans to do so secretly.

When an opportunity to leave home comes, the narrator knows where to go. By the time he arrived in Kampala, Uganda he had given up all his names. His namelessness affords the narrator a chance to reinvent himself. Isaac's dissonant self-narration discloses the guileless belief he had of making Kampala his home. "From the beginning, it was harder for Isaac than for me to be in the capital. This had never been and, I understood later, would never be my home, regardless of what I imagined" (5). He confesses how naïve he was in commit[ing] [him]self to thinking of [Kampala] only as "the capital [...] thinking as long as it was nameless, it had no allegiances. Like [him] it belonged to no one, and anyone could claim it" (4). The lack of a name and attachment to anyone makes the capital a place where anyone can belong, bringing out the cosmopolitan ideals of "openness, social justice, the universality of rights and principal of hospitality" (Delanty, "A cosmopolitan approach to the explanation of social change" 338). It is a place that respects cultural differences and is willing to engage with the other. Isaac thought he had a right to claim the capital as his home, but he later realises this will never be the case because of the power hierarchies of class and nationalist discourses at play in cosmopolitan mobilities that determine who belongs and who does not. In the capital the narrator finds himself always on the margins, isolated as a foreigner and poor boy from a small village in Ethiopia.

The narrating self uses interior monologue to comment on his feelings as an experiencing self. He states: "Isaac was gifted at making you feel special" (Names 8), revealing how important Isaac was to him as a friend. Mieke Bal describes interior monologue as "an artificial mode of narration in first person with character-bound narrator that seeks to eliminate reference to the first-person voice in favour of a silent 'pure' first person focalizer" (30). The 'you' here is used for self-address. Here the narrator discloses that, although he is powerless around his friend Isaac with his "conspiratorial language" such as "we should talk in private or let's talk someplace else" (Names 8) and with his eagerness to please him, causing him to quickly nod in agreement with whatever he says, this makes him feel special. His dependence on his friend Isaac grows with time to the point where the narrator feels safe and can only sleep better on campus with Isaac around.

The narrator discloses that his friendship with Isaac was built on the understanding that "both were liars and frauds" (7), pretending to be students at the university so as to belong. Isaac, just like the narrator, arrives in the capital thinking he can easily find his place. Unlike the narrator who is from Ethiopia, Isaac is more rooted in Uganda, but because he is a poor boy from the village he is marginalised too. Isaac's alienation is due to the society's social structure, where the difference between the privileged and non-privileged classes isolates the latter, heightening their sense of not belonging. The narrator reveals how they become friends through their common alienation in the capital. We became "friends the way two stray dogs find themselves linked by treading the same path every day in search of food and companionship" (6).

Days later they meet on campus trying their best to belong by "standing near but never too close to a group of students" (7). From the moment their eyes meet they see some familiarity in each other which the narrator describes as "only two men meeting unexpectedly in the middle of a desert after having travelled for so long that they've begun to believe the world was uninhabited would know what we felt like" (7). In the slums they didn't recognise each other but here on campus they are everything to each other. The description evidently demonstrates the isolated lives the narrator and his friend Isaac have in Kampala. Because of their poverty, they only manage to stay as poor squatters in marginalised slums away from the city. Seeing some familiarity in their alienation, the two become friends.

Their friendship blossoms over the games they play together at the university. They come up with a game of identifying two camps of students- the real revolutionaries and the campus frauds. They categorise members of the two camps simply by looking at the shoes the students are wearing. The real revolutionaries are those "who fought to be here" and wear "dusty shoes that had been repaired so many times till there was hardly anything left of the sole" (25) while the campus frauds are the boys who arrive in "chauffeured cars" (24). At the start of their game, the narrator does not care about the difference between the two camps because he is of the opinion that a third camp exists—outsiders like him who watch safely from the margins. He later realises the importance 
of learning to see the difference between the two camps because he had imagined "in the university were better rules" (25) of equality and inclusion. It does not take long to see the students as "part of the same campus body but fractured into dozens of discrete parts that loosely connected but rarely touched" (25). The narrator's observation indicates that the politics of belonging is not spared, even within the university community. The students who showed signs of wealth had privileges that "lifted their heads and focused their eyes" (25), something that could not be said of the likes of Isaac and the narrator who try their best to be part of the student body, but remain marginalised.

Using this game, Mengestu presents the social divisions in the city, depicting the disparity between the rich and the poor through the image of shoes. The foreigners, like the narrator, and the poor, like his friend Isaac, lack a sense of belonging in Uganda because the country only recognises those who have economic strength that can give them access to power and entitlement. This also illustrates the unfulfillment of the promise of Kampala as a city one can claim as home for ordinary individuals such as the narrator and Isaac.

Other than his friendship with Isaac, the narrator's life in Uganda is marked by absolute isolation. No one notices him, either at the university or the slum where he lives. A few months after meeting Isaac and for the first time since coming to the Kampala, the narrator feels that it is a place where he finally belongs. This does not last long because he finds himself all alone once again after Isaac's disappearance. In the weeks that follow, the narrator's loneliness intensifies as he offers:

Before Isaac, I had always been content to cast myself as an outsider, because only by such measures, I thought, could you break from the grips of the family and tribe around which you were supposed to order your life. I had ventured far away from home to live up to that idea without understanding that, inevitably, something had to be paid for it. Every day following Isaac's absence, I was reminded that without him I made no impact on no one. I was seen, and perhaps occasionally heard strictly by strangers, and always in passing. I was a much poorer man for this than I had ever thought. (46, emphasis added)

This narration, which sees his past decisions in retrospect, highlights a change in perception about the value of family and community. The narrator looks back at his naïve self and his decision to leave home, and now fully understands his loss, which at the time he could not grasp. The use of second person focalisation (italicised) allows the narrator to distance and evaluate his actions as an experiencing self. The narrator conveys his pain of loss and alienation in Kampala. The narrator's need to belong and feel a connection with the society is underscored in one instance when a boy he mistook for Isaac waves at him. The narrator is so elated that someone had actually noticed him that he stands there for more than one minute waving back at that boy.

At the height of the revolutionary violence in the capital, Isaac gives a nameless man some money to take the narrator to "someplace safe" (211). The narrator's presence in that village is "not totally welcome" but because Isaac had paid for his safety and for his stay there, his presence is just "tolerated" (219). The anonymity and quietness the narrator enjoys in the village initially, quickly wears off and every time the children shout his name, Daniel, it is a reminder of his "privileged perch" (219). The curious gazes from other villagers and the excitement from children shouting hello at him every day remind him of his status as an outsider in the village and sometimes, as the narrator offers, "I could hear the imaginary perch I lived on break" (220). The privileged perch he enjoys in the village makes him understand why his father called him a "bird" (219) who "lived high in the sky, far above everyone else" (179).

The image of the bird symbolises the detachment of the narrator from the host community. The narrator enjoys watching the villagers go about their daily activities but can't be part of it. This perch emphasises his sense of not belonging there but being temporarily accepted, underscoring the experiences of immigrants in host communities as never fully recognised as part of the new places they move to. The bird image also indicates the narrator's freedom and his quest for a place where he would belong. As a boy back in the village, the narrator always wanted to leave because he felt like he did not belong there. After arriving in Uganda, he thinks he can make the capital his home but that does not happen because he is not accepted. Just like the bird that flies from one branch to the next, the narrator is in a continued search for a place to belong. With no fixed place to belong, the narrator's identity is not fixed but fluid, continually in a process of adapting to new places. These shifts present him the opportunity to reinvent his identity, therefore achieving plural and hybrid identity.

Isaac's selfless act of giving the narrator his student visa enables the narrator to travel to America under his name, Isaac Mabira, consequently escaping the war in Uganda. Isaac's act reflects Kwame Gyekye's argument that "humanity, not our particular 'ethnic' background, should constitute our fundamental identity" (103) because 
"it is the individual, worthy of dignity and respect, not the ethnic group, who ought to be considered" (103). In the novel Mengestu underscores that "friendship can be the basis of a deeper and more inclusive democracy as it is a relationship that goes beyond the proximity of familial, ethnic, or national relations" (Derrida, The Politics of Friendship vii). This is exemplified by the friendship between the narrator and Isaac. Despite their differences, the narrator being Ethiopian and the friend Isaac being Ugandan, their friendship is cemented on their experiences as marginalised individuals in Kampala.

To present Isaac's experiences in America, Mengestu uses Helen's perspective which is important in the novel as it presents the view of an individual from within the centre, not on the margins like Isaac. From her perspective, Isaac displays more maturity, and is a person who feels that he does not belong to this new place and is thus ready to live as quietly as possible. Helen's narrative is significant in telling of Isaac's life in America and how her encounter with Isaac makes her realise the extent of the racial discrimination in her town which, as she confesses, she only noticed in extreme forms.

In the novel, Mengestu uses Isaac's interracial love affair with Helen to reveal the limits of cosmopolitan ideals of openness to otherness in America, where race is the power that differentiates and classifies individuals, deciding who belongs or does not belong. In the town of Laurel, race influences social relationships by fixing individuals in definite groups, thus denying people the chance of moving past these boundaries of race and engaging with the other. The town's racist attitudes are captured in Helen's description: "we were exactly what geography had made us middle of the road, never bitterly segregated, but with lines dividing black from white all over the town, whether in neighborhoods, churches, schools, or parks. We lived semi-peacefully apart" (33).

Because of the racial prejudice in the town, Isaac's relationship with Helen unfolds exclusively in his apartment. Back in Uganda, Isaac had a fantasy of finding a foreign wife - probably a doctor, with blonde hair and blue eyes-who would fall in love with him despite their racial and class differences. He imagined them having a kind of love that frees an individual from the broken world. Here in Laurel, Isaac gets to understand that this kind of love is not a possibility outside his apartment. Their relationship is "an isolated reality that begin[s] and end[s] on the other side of his apartment" (21). They are also aware of "how easily the tiny world [they were] slowly building could vanish" (21) if the outside world found out about their affair. I read Helen's sexual desire towards Isaac as a "mode of opening [her]self to the strangeness of the other [Isaac]; a risky movement of giving up [her] identity and entering the strange territory of the other [thus] creating possibilities for dialogue" (Pucherova 932). Despite the racism in Laurel, Helen risks it all to be in a relationship with Isaac.

Helen's longing to have a relationship with Isaac, like other normal couples, and to have a chance to "go to the movies, dinner, invite friends over on the weekend, and have beach vacations" (Names 32) makes her single-handedly challenge the racism in Laurel. To start her small revolt, she invites Isaac out for lunch at Ben's diner. She describes the diner as "never officially segregated" although only whites eat there (35). Isaac and Helen walk into Ben's diner together and immediately "the whole diner fell silent as all eyes turned towards them" (36). In the midst of the stares which confirm that Isaac has transgressed the fixed racial boundaries by stepping into Ben's diner, the waitress takes their order.

The waiter comes back after a while to ask them if they would like their food as takeaway because Isaac's presence is not welcome. Isaac, realising what is going on, insists they will eat in the restaurant. The waitress brings Isaac's order first, "served on a stack of thin paper plates barely large enough to hold the food [with] a plastic fork and knife wrapped in a palm-sized napkin" (38). Later, Helen's order is delivered, served on "standard cream-colored plates used for everyone other than Isaac" (38). Isaac is treated as an inferior being not worth the same treatment as Helen, simply because of his skin colour. Mengestu contests such racial prejudices, arguing against forms of identity grounded in race that are used to justify forms of oppression and exclusion of some individuals based on their skin colour. The stares that Helen and Isaac receive at Bill's diner are the same hostile glares they receive when they stop for lunch at a restaurant off the highway on their journey to Chicago. The waitress who serves them addresses both as "dear" and "honey" (225), an enacted affection to hide the obvious racism surrounding them.

Henry's advice to Isaac for how to live in America highlights the normalisation of racism in Laurel. "[Henry] told me not to stare at white people, to say 'sir' if I was stopped by the police, and to live as quietly as possible" (177). Isaac takes Henry's advice by trying to avoid unnecessary attention to himself, especially when with Helen. This is seen when Helen and Isaac take a drive to a motel far away from town. As they drive into the motel's parking lot, Helen does not display any fear of them being seen together, but Isaac "insist [s] on sliding to the bottom of 
the seat because even though [the people] don't know [Helen], they still might not like what they see" (150). His actions display his understanding of the racism in America and reactions to his identity as a black man in such a society.

Due to the racial discrimination that Isaac has to confront in America, his life in Laurel is steeped in loneliness. The only people Isaac can talk to are Helen and Henry. Isaac depends on Helen for almost everything, and on one occasion he calls her at work to ask her to leave the phone on the desk so that he can hear other people talking. Isaac's request exemplifies his isolation in Laurel. Helen reveals that Isaac "didn't know how to fill his days. He had books [...] that he read obsessively because he didn't know what to do with all those empty long hours" (22). Helen pities Isaac "for having nothing that was truly his" (22). Isaac has no place he belongs to or can call home. Helen observes that "being occasionally called 'boy' or 'nigger' didn't compare to having no one who knew him before [coming to America], who could remind him, simply by being there, that he was someone else entirely" (22). Helen's statements underline Isaac's estrangement and alienation. Estranged from his family and alienated in the new places his finds himself, Isaac is a permanent outsider and he acknowledges that there is no place in the world where he could feel at home. Isaac is in a liminal state; he is in a constant negotiation between a past that is lost and a present that is not definite. This gives him a plural and hybrid identity that challenges conventional notions of identity and belonging. Mengestu uses Isaac, who is always on the margins because of his difference, to counter celebratory cosmopolitanism and highlight power hierarchies at play in society that control mobilities across borders.

\section{Names as sites for negotiation of identity}

In the novel, Mengestu, through the character of Isaac, tackles the question of naming, unnaming, and renaming and how it connects to identity as a fluid concept. Isaac's search for identity is constructed around his flight from his own names and his past in a need to reinvent himself across borders. Growing up in his village, Isaac professes his desire to leave home because he always felt like a stranger. Even before leaving home, Isaac had given himself different names - though he does not disclose them-in addition to the others he gets in the course of the narrative. In All Our Names, names are used as a narrative device to illustrate that identity is not singular or fixed but plural and continuous.

According to Janet, a name "personifies the individual and is also a symbol of uniqueness of the individual" (711). This makes the name "a rigid designator that can attribute identity and impute properties to an object or an individual" (Kripke 48). Naming, as Ganapathy-Dore states, "follows birth, a christening that endows an individual with an identity and inserts the individual in a clan or religious or national community" (17). This is the case with Isaac as he narrates "when I was born, I had thirteen names. Each name was from a different generation, beginning with my father and going back from him. I was the first one in our village to have thirteen names. Our family was considered blessed to have such a history" (Names 177). This statement underlines the importance of names in Isaac's community and family. For them, names reflect the culture, history, and memory of the community and group consciousness. For the community, naming, as Derek Alderman argues, is "a powerful vehicle for promoting identification with the past and locating oneself within the network of memory" (195). Isaac did not share in the pride of having all these names as he confesses: "I knew from a very young age, though, that I would never want that. I felt as if I had been born into a prison" (Names 177-8).

In his quest to free himself from this prison, he decides to drop his names as he crosses the border from Kenya to Uganda: "I shed those names just as our bus crossed the border into Uganda" (3). Isaac's action reaffirms Derrida's argument that "we are not our names or titles; the named may break free from their received names" (On the Name 12-3). Derrida's statement indicates that names are not fixed entities. This is also emphasised by Bodenhorm and Vom Bruck's argument that "naming, name dropping and name changing demonstrate the processual nature of embodied practice and the dynamic of identification" (20).

I read into Isaac's interest in leaving home and acquiring new names a desire for the freedom to reconfigure and reconstruct himself as a cosmopolitan self away from the singularity and confinement of the community's culture. Even before he had a chance to leave home, Isaac had begged his father to send him away, unsuccessfully. So Isaac had to make his own plans to leave. When what started as rumours of a socialist revolution unfolded into reality in their village, the narrator's father realised it is time for his son to leave home. Isaac thus left his home for Uganda. By the time he arrived in Kampala, Isaac was a nameless entity and that suited him perfectly. 
Kimberly Benston argues that the act of unnaming involves the power of the sublime, a transcendent impulse to undo all categories, all metonymies and reifications, and thrust the self beyond the received patterns and relationships into a stance of unchallenged authority (4). Isaac's nameless status gives him the power to redefine himself through renaming and experience "a plurality of identities" (Kroetsch 52). Dropping all his names and remaining unnamed gives Isaac a chance to attain a plurality of identities through the different nicknames and names he adopts or is assigned in the novel.

The first time the narrator meets with his friend Isaac in Uganda at the university, Isaac nicknames the narrator "professor [because] with his skinny legs and narrow face he looked more like a professor than a fighter" (Names 4). The narrator does not protest against the nickname because he always "wanted to be a famous writer surrounded by like-minded men" (4). Therefore, that name corresponds to a part of himself. Accepting the nickname is a way of envisaging his dream of becoming a writer. From that moment Isaac takes to calling him "Professor or the Professor" (5). This marked the start of their friendship.

Later, in celebration of the paper revolution victory, Isaac suggests that is time for the narrator to choose a different name for himself. "You're no longer just the Professor [...] it's time you moved to something new. Choose someone famous, but not too famous" (40). The narrator chooses Langston because Langston had earlier attended the conference of writers at the university that gave shape to his early ambitions and the narrator instantly felt attached to this name. Here, the narrator associates himself with the famous Langston Hughes, therefore identifying with his dream of becoming a famous writer in the future and signalling his desire to be part of the global world by having a cosmopolitan existence. By picking the name Langston, Isaac affirms Rebecca Walkowitz' argument that "nicknames are informal, unofficial and improper but intimate partial appellations that register a diversity of selves" (143).

The day the narrator is released from hospital after he was beaten and left for the dead, his friend Isaac decides to give him another nickname, ironically stating "you look good. I'm going to call you Ali from now on" (Names 104). In nicknaming the narrator Ali, Isaac emphasises his status as an outsider in the society and a symbol of "Foreign terrorist threat to the nation" (88). By that time, the narrator is homeless because his landlord, Thomas, had kicked him out, citing that the narrator was in trouble with the government.

After war erupts in Uganda, the narrator is offered a chance to escape to The United States of America. In the small American town of Laurel, he meets Helen who nicknames him Dickens because his "English was perfect like someone talking in a Dickens' novel" (17). This is because, before Isaac left his home in Ethiopia, he had read the same Victorian novels a dozen times and assumed that was how proper English was spoken. The Victorian novels offer Isaac a perception of another distant culture which moulds his cosmopolitan attitude. This exemplifies Appiah's argument that "cultural purity is an oxymoron [because individuals] already live in a cosmopolitan life enriched by literature, art and film that come from many places and that contains influences from many more" (113).

In addition to the nicknames that Isaac is given and gives himself in the novel, Isaac is also renamed twice under different circumstances. The first instance is when his friend Isaac pays an old man and his son to take Isaac to their small village where it is safe during Joseph's war. On their journey there Isaac told them his birth name but "by the time [they] arrived at the village his name had been transformed into Daniel-a Biblically familiar name among the devoutly Christian people who lived there" (Names 213). This transformation of Isaac's name calls to mind Ganapathy-Dore's remarks about names in times of migration. She observes that names can be "shortened in length, altered in terms of spelling and pronunciation and can be changed to acclimatize to a different language" (20-1). Even though his name is converted to be acceptable in his new temporary home, it does not do much to camouflage his presence as an outsider there. As he says, while in the village at first he enjoyed hearing the children say the name as it sounded like a song. This attention later on becomes a "reminder of his place as a curious stranger-not totally welcome, but easily tolerated" (Names 219).

According to Bodenhorm and Vom Bruck, names have the potential to fix an individual as a member of a certain recognised social group; their detachability makes names a powerful tool for establishing or erasing formal identity because names can be stolen, traded, suspended, and even erased (2-4). Their argument on the detachability of names is evidenced throughout the novel as the protagonist drops his names and picks different names in the course of the narrative. Later, at the height of the war in Uganda, his friend Isaac reassigns him his own name, Isaac, when he allows him the use of his student visa in order to give him the means of escaping the ongoing war through travelling to America. 
As the narrator recalls, he "became Isaac as soon as he stepped on the plane" (Names 175). Clara Locatelli remarks that Isaac's "naming and name appropriation signal a procedural construction of an on-going identity" (qtd in Francesconi 8). It is in the last chapter that Mengestu reveals Isaac's birth name as "D-" (Names 253) which does not do much to end his anonymity in the novel. Through Isaac, Mengestu, constructs names as "never definitive products but as performative and open textual units" (Francesconi 2). Isaac's anonymity gives him the freedom to be named and renamed, "signal[ing] a refusal of finality, of ending up the self, proffer[ing] instead the hope of endless renewal" (Benston 9), making the act of naming and the use of names in the novel an on-going performative process. The narrator takes Isaac Mabira's passport that does not have Isaac's picture and makes it his own. Once again, he sheds off his identity, picking a new one that would allow him to leave the African continent. This underscores how migrants have to reinvent their identities in the face of danger in order to survive.

\section{Conclusion}

In All Our Names Mengestu illustrates that a name is not enough to answer the question "who are you?" because an individual is made up of stories and experiences. Mengestu shares a similar sentiment in his argument that questions such as "who are you?" or "where do you come from?" tend to cast individuals into singular solutions, a notion he decries. According to Mengestu, "identities can be and should be much more fluid and much more layered" (Mengestu and Reed). All the names that Isaac acquires in the novel convey the meaning of the novel's title, All Our Names, which imply that identity is layered, and all the names individuals acquire in their lifetime make up their identity.

In this article I have focused on how Mengestu presents the limits of a cosmopolitan world through the figure of Isaac, who is in search of a cosmopolitan existence away from home. In juxtaposing Isaac's sense of alienation in Uganda and America, Mengestu highlights the politics of identity and belonging in postcolonial Africa and America. In Uganda, Isaac has to confront the politics of ethnicity, class, and nationalist discourses of belonging that prevent him from making a home in Kampala. In America, he cannot belong as a racialised other and his close relationship with Helen is considered inappropriate.

Helen's perspective is very significant in the novel for presenting the views from the 'centre' with regard to racism in Laurel. Her romantic relationship with Isaac opens her eyes to racism in the town which prompts her to challenge this Othering of individuals because of their skin colour. Mengestu uses her to show that, if the question of race is to be conquered, it has to start from within the centre- the whites should be willing to engage with and accept the other. Mengestu also uses names as a narrative strategy in order to show that identity is never singular or fixed. The performative act of naming and renaming in the novel signifies and complicates the possibility of a single marker in containing an individual's identity. Migrants' identities are influenced by the past, present, and their daily experiences in the places they move to. As they try to adapt to these new places, they are forced to drop their names and take on new ones in their quest for inclusion and belonging. This shows that identity is both plural and hybrid because it is influenced by the politics and power structures in society, and is therefore always in the process of becoming.

\section{Works Cited}

Alderman, Derek. "Place, Memory and the Interpretation of Cultural Landscapes." The Ashgate Research Companion to Heritage and Identity, edited by Brian Graham \& Peter Howard. Ashgate, 2008, pp. 195-213.

Appiah, Kwame A. Cosmopolitanism: Ethics in a World of Strangers. W. W Norton, 2006.

Ashcroft, Bill. "Beyond the Nation: Post-Colonial Hope." The Journal of the European Association of Studies on Australia vol. 1, 2009, pp. $12-22$.

Bal, Mieke. Narratology: Introduction to the Theory of Narrative. U of Toronto, 1997.

Benston, Kimberly. "I Yam what I Am': Naming and Unnaming in Afro-American Literature." Black American Literature Forum vol. 16, no. 1, 1982, pp. 3-11. DOI: https://doi.org/10.2307/2904266.

Bhabha, Homi K. The Location of Culture. Routledge, 1994.

."The Third Space." Identity, Community, Culture, Difference, edited by Jonathan Rutherford. Lawrence \& Wishart, 1990, pp. 207-21.

Bodenhorn, Barbara \& Gabrielle Vom Bruck. The Anthropology of Names and Naming. Cambridge U P, 2006.

Boucher, Francois, Isabelle Aubert \& Sophie Guérard de Latour. "Approaches to Cosmopolitanism: Review Essay on Their History, Analysis and Application to the EU." NOVAMIGRA, 2019, pp. 1-49.

Chakraborty, Arup R. "Liminality in Post-Colonial Theory: A Journey from Arnold van Gennep to Homi K. Bhabha." Anadhyun: An International Journal of Social Sciences (AIJSS) vol. 1, no. 1, 1996, pp. 145-53. 
Culler, Jonathan. Literary Theory - A Very Short Introduction. Oxford U P, 2006.

Delanty, Gerard. "A cosmopolitan approach to the explanation of social change: social mechanism, processes, modernity." The Sociological Review vol. 60, no. 2, 2012, pp. 334-54. DOI: https://doi.org/10.1111/j.1467-954X.2012.02076.x.

."The Cosmopolitan Imagination: Critical Cosmopolitan and Social Theory." The British Journal of Sociology vol. 57, no. 1, 2006, pp. 25-47. DOI: https://doi.org/10.1111/j.1468-4446.2006.00092.x.

Derrida, Jacques. On the Name, edited by Thomas Dutoit. Trans. David Wood, John P. Leavey Jr. \& Ian McLeod. Stanford U P, 1995. . The Politics of Friendship. Verso, 1997.

Finch, Janet. "Naming Names: Kinship, Individuality and Personal Names." Sociology vol. 42, no. 4, 2008, pp. 709-25. DOI: https://doi.org/10.1177/0038038508091624.

Francesconi, Sabrina. "Negotiating of Naming in Alice Munro's 'Meneseteung." Journal of the Short Story in English vol. 55, 2010, pp. 1-10.

Ganapathy-Dore, Geetha. "Playing Hide and Seek with Names and Selves in Salman Rushdie's Joseph Anton, A Memoir." Atlantis vol. 35, no. 2, 2013, pp. 11-25.

Georgiou, Myria. Diaspora, Identity, and the Media: Diasporic Transnationalism and Mediated Spatialities. Hampton, 2006.

Gyekye, Kwame. Tradition and Modernity: Philosophical Reflections on the African Experience. Oxford U P, 1997.

Hadja, Jan. "Alienation and Integration of Student Intellectuals." American Sociological Review vol. 26, no. 5, 1961, pp. 758-77. DOI: https://doi.org/10.2307/2090205.

Hall, Stuart. "Who needs Identity?" Questions of Cultural Identity, edited by Stuart Hall \& Paul Du Gay. SAGE, 2000, pp. 15-30.

Hook, Derek. "Frantz Fanon, Steve Biko, 'psychopolitics' and critical psychology." LSE Research Online, 2004, pp. 84-114

Kripke, Saul A. Naming and Necessity. Harvard U P, 1980.

Kroetsch, Robert. "Canadian Writing: No Name is My Name." The Forty-Ninth and Other Parallels: Contemporary Canadian Perspectives, edited by David Staines. U of Massachusetts, 1986, pp. 116-28.

McCallum, Robyn. Ideologies of Identity in adolescent Fiction: The Dialogic Construction of Subjectivity. Garland, 1999.

McLeod, John. Beginning Postconialism. Manchester U P, 2000.

Mengestu, Dinaw. All Our Names. Hodder \& Stoughton, 2014

Mengestu, Dinaw \& Josephine Reed. "Big Read interview with Dinaw Mengestu." National Endowment for the Arts. 18 Jun. 2017. https:/www.arts.gov/stories/other/big-read-interview-dinaw-mengestu.

Pollock, Sheldon I. et al. "Cosmopolitanism." Public Culture vol. 12, no. 3, 2000, pp. 577-89.

Pucherova, Dobrota. "Re-Imagining the Other: The Politics of Friendship in Three Twenty-First Century South African Novels." Journal of Southern African Studies vol. 35, no.4, 2009. pp. 929-43.

Sacks, Sam. "The Rise of the Nameless Narrator." The New Yorker. 3 March 2015. https://www.newyorker.com/books/pageturner/the-rise-of-the-nameless-narrator.

Vertovec, Steven \& Robin Cohen. Conceiving Cosmopolitanism: Theory, Context and Practice. Oxford U P, 2002.

Voronkova, Anastacia. “Are Nationalism and Cosmopolitanism Compatible?" e-International Relations. 25 Nov. 2010. https:// www.e-ir.info/2010/11/25/are-nationalism-and-cosmopolitanism-compatible/.

Walkowitz, Rebecca L. Cosmopolitan Style: Modernism Beyond the Nation. Columbia U P, 2006.Werbner, Pnina. "Vernacular Cosmopolitanism." Theory, Culture and Society vol. 23, no. 2-3, 2006, pp. 496-98. DOI: https://journals.sagepub.com/doi/10. $\underline{1177 / 026327640602300291 .}$. 